\title{
ДИФФЕРЕНЦИАЦИЯ ЗАРАБОТНОЙ ПЛАТЫ В НАЦИОНАЛЬНОЙ ЭКОНОМИКЕ БЕЛАРУСИ В КОНТЕКСТЕ СОВРЕМЕННОЙ ТЕОРИИ РЕНТЫ
}

\author{
Т.Н. Долинина*
}

Проанализирована дифференциация заработной платы в национальной экономике Беларуси в региональном, межотраслевом, профессионально-квалификационном и гендерном ее аспектах с позиций авторской теоретической концепции социально-трудовой ренты. Исследована структура средней заработной платы. Выявлены проблемы управления оплатой труда и основные пути их решения.

Ключевые слова: заработная плата, дифференциация, социально-трудовая рента, абсолютная рента, дифференциальная рента, монопольная рента.

JEL-классификация: J31, J59, E24.

DOI: $10.46782 / 1818-4510-2021-3-83-99$

Материал поступил 17.08.2021 2.

Международная организация труда констатирует нарастание ряда негативных тенденций в социально-трудовой сфере, к числу которых относятся: сохранение значительной дифференциации заработной платы между странами; резкое углубление дифференциации заработной платы между предприятиями и внутри них; сохранение гендерной сегрегации; дискриминация отдельных групп работников, страдающих от разницы в заработной плате, необъяснимой различиями в образовании и опыте работы; рост числа низкооплачиваемых наемных работников, усложняющий борьбу с бедностью; возрастание социальной напряженности вследствие углубления неравенства в оплате труда ${ }^{1}$. Развитие неблагоприятных мировых трендов в оплате наемного труда вызвало стремительный рост числа исследований и расширение исследовательского фронта работ по экономике труда, ко-

${ }^{1}$ Global wage report 2018/19: what lies behind gender pay gaps. Intern. Labour Organization. Geneva: Intern. Labour Office, 2018. URL: https://www.ilo.org/wcmsp5/groups/ public/-dgreports/-dcomm/-publ/documents/publication/ wcms_650553.pdf торый фиксируется международными наукометрическими базами (Башина, Матраева, Васютина, 2019).

Большинство из перечисленных проблем характерно и для социально-ориентированной экономики Беларуси, их накопление препятствует инклюзивному развитию нашего общества, в котором более $96 \%$ занятого населения являются наемными работниками. В этой связи особо следует отметить разрушающие трудовую мотивацию диспропорции в размерах заработной платы работников различных профессионально-квалификационных групп, реализующих свои способности к труду в рамках разных субъектов хозяйствования, функционирующих в различных видах экономической деятельности.

Между тем до сих пор дифференциация заработной платы в отечественной экономике труда не являлась центральной темой научных исследований, в их фокус чаще попадали вопросы, связанные с функционированием различных элементов механизма оплаты труда в национальной экономике,

* Долинина Татьяна Николаевна (tdolinina@mail.ru), доктор экономических наук, Белорусский государственный технологический университет (г. Минск, Беларусь). https://orcid.org/0000-0002-9021-2255 
разработкой прогнозных и программных документов, определяющих политику в сфере оплаты труда. Однако формирование целостного эффективного механизма оплаты труда невозможно без понимания природы дифференциации заработной платы по регионам, видам экономической деятельности, субъектам хозяйствования, профессионально-квалификационным и гендерным группам работников. В этой связи автором на основе анализа существующих научных подходов и обобщения многолетних статистических данных, отражающих дифференциацию заработной платы в национальной экономике в указанных ракурсах, была разработана теоретическая конщепиия сощиально-трудовой ренть, раскрывающая происхождение дифференциации заработной платы в контексте современной теории ренты ${ }^{2}$. Применение этой концепции способствовало выявлению ключевых проблем белорусской модели управления оплатой труда и определению основных направлений ее развития.

\section{Теоретическая концепция заработной платы как социально-трудовой ренты}

Идея описания заработной платы как рентного дохода витает в экономической науке уже более двух веков. В частности, она присутствует в трудах И.Г. Буша, Ф. фон Шторха, Дж.Б. Кларка, А. Маршалла, Н.Г. Мэнкью, Дж. Бомола, А.С. Блайндера, Б.М. Генкина, А. Безгодова, М. Рудакова, Д. Давыдова, в теории человеческого капитала ${ }^{3}$ (Безгодов, 2017; Генкин, 2016; Давыдов, Фишман, 2015; Рудаков, 2015; Becker, 1993; Schultz, 1971). Однако до сих пор в теории заработной платы отсутствуют системные теоретические построения, выполненные в контексте современной теории ренты.

Оригинальность авторской концепции социально-трудовой ренты состоит в том,

\footnotetext{
2 Долинина Т.Н. 2019. Институциональные модели управления оплатой труда. Ч. 1. Минск: БГТУ. С. 198-227.

${ }^{3}$ Бомол У.Дж., Блайндер А.С. 2004. Экономикс: принципы и политика: учебник. Москва: ЮНИТИ-ДАНА. 893 с.; Генкин Б.М. 2016. Мотиващия и организация эффективной работы: теория и практика. Москва: Норма: ИНФРА-М. 352 с.; Кларк Дж.Б. 1992. Распределение богатства. Москва: Экономика. 447 с.; Маршалл А. 2008. Основы экономической науки. Москва: Эксмо. 830 с.; Мэнкью Н.Г. 2009. Приниипь макроэкономики. Санкт-Петербург: Питер. 544 c.; Büsch J.G. 1975. Abhandlung von dem Geldumlauf. Glashutten im Taunus: Auvermann. 684 p.
}

что заработную плату предлагается рассматривать как рентный доход работника, образуемый в результате применения его способностей к труду в конкретной хозяйственной системе как определенной комбинации факторов производства. Уровень этого дохода зависит как от конкурентоспособности работника в хозяйственной системе, так и от конкурентоспособности самой хозяйственной системы, позволяющей ей иметь ренту в виде добавленной стоимости, выступающей источником выплаты заработной платы. Получение заработной платы как рентного дохода невозможно без участия общества в формировании способностей работника и построении хозяйственной системы, обеспечивающей реализацию в ней этих способностей, что и обуславливает понимание заработной платы как сощиально-трудовой ренты, создаваемой совместно трудом работника и усилиями общества.

Поскольку труд может предполагать разную квалификацию исполнителей, быть воспроизводимым или уникальным и применяться в различающихся по эффективности хозяйственных системах, то в составе заработной платы может присутствовать абсолютная, дифференциальная и монопольная социально-трудовая рента. Абсолютная рента минимально возможная стоимость воспроизводства ресурсов жизнедеятельности работника как биосоциального существа (минимум средств существования). Дифференциальная рента - дополнительный доход работника сверх абсолютной ренты, обусловленный лучшими способностями к труду и (или) условиями их реализации в конкретной хозяйственной системе. Под монопольной рентой понимается дополнительный доход работника, связанный с уникальностью его способностей к труду и (или) их реализацией в уникальной хозяйственной системе с редкими факторами производства (рис. 1). Отсюда заработная плата может быть представлена как функция, имеющая три аргумента: минимум средств существования; уровень конкурентоспособности работника или функциональная значимость его способностей к труду для конкретной хозяйственной системы; уровень конкурентоспособности хозяйственной системы. Эта формула показывает, что факторы производства, обеспечивающие конкурентоспо- 
Дифференциация заработной платы в национальной экономике Беларуси ...

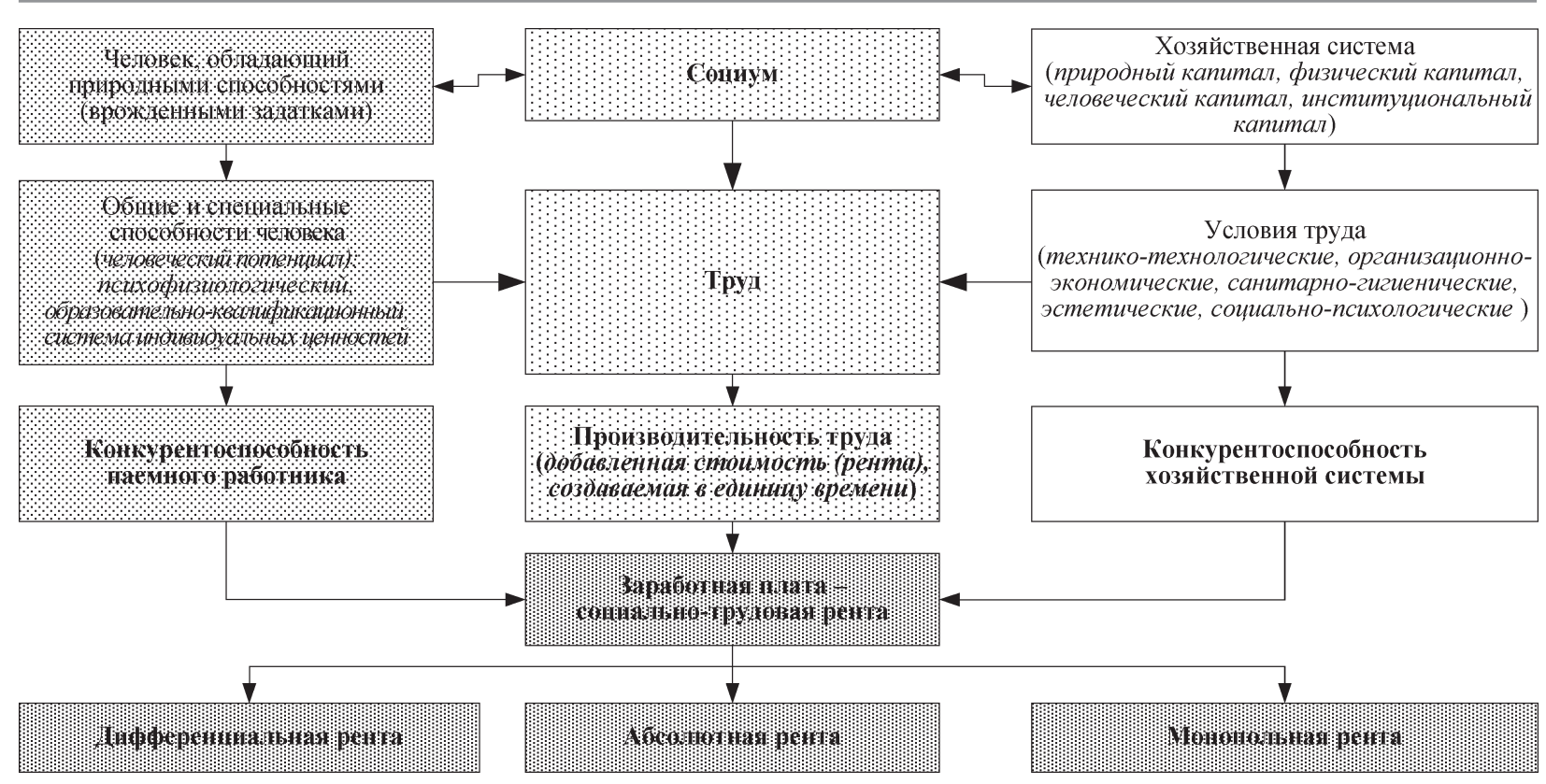

Рис. 1. Формирование заработной платы как социально-трудовой ренты

Источник. Авторская разработка на основе результатов исследования.

собность хозяйственной системы, определяют дифференциацию заработной платы работников с одинаковыми способностями к труду, но реализованными в разных хозяйственных системах.

Таким образом, авторская концепщия соииально-трудовой ренть предусматривает применение принципиально нового подхода к анализу заработной платы как экономической категории, согласно которому в рентной структуре заработной платы присутствуют абсолютная, дифференциальная и монопольная ренты. Изучение этих составляющих и структуры в целом дает возможность оценить силу влияния различных факторов на формирование уровня заработной платы и на этой основе сформулировать подходы к наращиванию потенциала национальной модели управления оплатой труда.

\section{Дифференциация заработной плать в нащиональной экономике Беларуси}

В течение двух десятилетий в Беларуси сохранялась небольшая дифференциация доходов населения - коэффициент Джини колебался в диапазоне 0,27-028, что близко к его значению в самых благополучных странах Западной и Северной Европы. Однако сегодня в отечественной экономике наблюдаются тревожные предпосылки к нарастанию неравенства в доходах населения.
Как известно, неравенство в доходах зарождается на рынке труда. Данные Национального статистического комитета Республики Беларусь (Белстата) отражают рост дифференциации заработной платы в белорусской экономике. Так, если в 2013 г. медианная заработная плата составляла около 83\% от средней, то в 2021 г. - ниже $72 \%$. При этом среднемесячная заработная плата не демонстрировала опережающего роста по сравнению с минимальным потребительским бюджетом трудоспособного населения (МПБ $)$, соотношение этих показателей сохранилось на том же уровне 2,50 в 2013 г. и 2,52 в 2021 г. (табл. 1).

Отмеченные тенденции сказались на изменении распределения работников по заработной плате (рис. 2). Так, в 2020 г. по сравнению с 2013 г. возросла доля работников, получающих заработную плату в

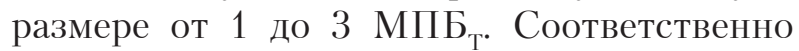
сократилась доля работников, получающих более высокую заработную плату.

Нарастание дифференциации заработной платы в Беларуси до сих пор не было ощутимым вследствие изменений в структуре доходов населения, связанных с сокращением доли предпринимательских доходов с 12,7\% в 2010 г. до 7,6\% в 2021 г. Нежелательность дальнейшего углубления дифференциации заработной платы обус- 
Дифференциация заработной платы в национальной экономике

\begin{tabular}{|c|c|c|c|c|c|}
\hline Период & $\begin{array}{c}\text { Медианная } \\
\text { заработная } \\
\text { плата, руб. }\end{array}$ & $\begin{array}{c}\text { Средняя } \\
\text { заработная } \\
\text { плата, руб. }\end{array}$ & $\begin{array}{c}\text { Соотношение } \\
\text { медианной } \\
\text { и средней } \\
\text { заработной платы, } \\
\%\end{array}$ & $\begin{array}{c}\text { Минимальный } \\
\text { потребительский } \\
\text { бюджет } \\
\text { трудоспособного } \\
\text { населения, руб. }\end{array}$ & $\begin{array}{c}\text { Соотношение } \\
\text { средней } \\
\text { заработной платы } \\
\text { и МПБТ, раз }\end{array}$ \\
\hline Май 2013 & 403,8 & 488,8 & 82,6 & 195,6 & 2,50 \\
\hline Май 2014 & 481,5 & 586,1 & 82,2 & 244,0 & 2,40 \\
\hline Май 2015 & 523,5 & 668,8 & 78,3 & 302,5 & 2,21 \\
\hline Май 2016 & 548,0 & 718,3 & 76,2 & 355,3 & 2,02 \\
\hline Май 2017 & 598,7 & 795,2 & 75,3 & 396,8 & 2,16 \\
\hline Май 2018 & 709,3 & 943,9 & 75,1 & 437,9 & 2,29 \\
\hline Май 2019 & 802,7 & 1071,6 & 74,9 & 467,2 & 2,39 \\
\hline Май 2020 & 893,9 & 1227,9 & 72,8 & 513,7 & 2,52 \\
\hline Май 2021 & 1018,4 & 1419,6 & 71,7 & 562,3 & \\
\hline
\end{tabular}

Источник. Авторская разработка на основе: Номинальная начисленная средняя заработная плата работников Республики Беларусь с 1991 по 2021 год. URL: https://www.belstat.gov.by/ofitsialnaya-statistika/realny-sector-ekonomiki/ stoimost-rabochey-sily/; Медианная заработная плата работников Республики Беларусь по видам экономической деятельности. URL: https://www.belstat.gov.by/ofitsialnaya-statistika/realny-sector-ekonomiki/stoimost-rabochey-sily/ operativnye-dannye/mediannaya-zarabotnaya-plata-rabotnikov-respubliki-belarus-po-vidam-ekonomicheskoy-deyatelnosti/ https://www.belstat.gov.by/ofitsialnaya-statistika/realny-sector-ekonomiki/stoimost-rabochey-sily/operativnye-dannye/ mediannaya-zarabotnaya-plata-rabotnikov-respubliki-belarus-po-vidam-ekonomicheskoy-deyatelnosti/

ловлена тем, что сегодня при невысоком среднем уровне заработной платы по стране в целом каждый четвертый работник получает низкую заработную плату (ниже 2/3 медианного значения).

Представленные оценки дифференциации заработной платы слишком укрупнены, а показатели заработной платы, усредненные по национальной экономике в целом, недостаточно информативны. В этой связи целесообразным является рассмотрение различий в заработной плате в регио-

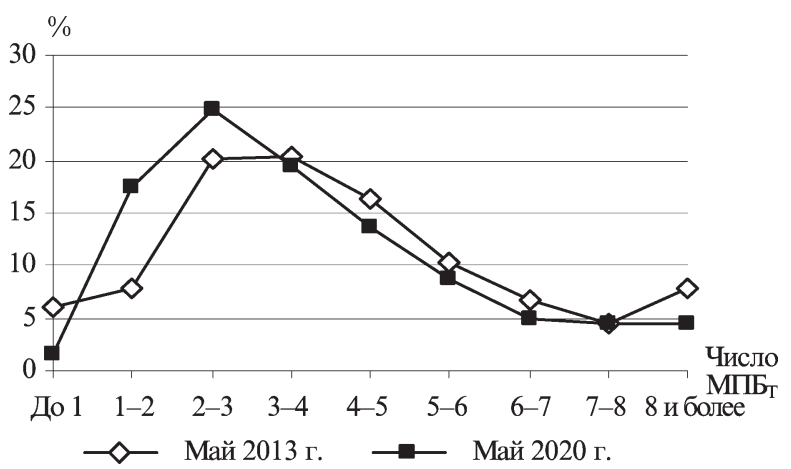

Рис. 2. Распределение работников по размеру начисленной заработной платы, измеряемой числом МПБ, 2013 и 2020 гг.

Источник. Авторская разработка на основе: Распределение численности работников по размерам начисленной заработной платы. URL: https://www.belstat.gov.by/ ofitsialnaya-statistika/realny-sector-ekonomiki/stoimostrabochey-sily/operativnye-dannye/raspredelenie-chislennostirabotnikov-po-razmeram-nachislennoy-zarabotnoy-platy/ нальном, межотраслевом, профессиональноквалификационном и гендерном аспектах.

\section{Региональная дифференциачия заработной плать}

В разрезе белорусских регионов самой высокой заработной платой и наиболее быстрым ее ростом характеризуется г. Минск, который, обладая статусом столицы, концентрирует значительную часть финансовых ресурсов страны. Самая низкая заработная плата до 2015 г. была традиционна для Брестской области, считающейся сельскохозяйственным регионом страны, однако в последние годы на последней позиции прочно обосновалась Могилевская область. Коэффициент межрегиональной дифференциации заработной платы, ранее отличавшийся стабильностью, в последние годы демонстрирует ее рост с 1,44 в 2013 г. до 1,75 в 2020 г. (табл. 2). Исключение из расчетов г. Минска с максимальной заработной платой сужает пределы дифференциации заработной платы по регионам страны до 1,09-1,22.

Заработная плата по областям (помимо Минской области) на 14-19\% ниже, чем в среднем по республике. Рассмотрение же ее дифференциации в рамках отдельных областей на основе данных выборочного обследования, выполненного Белстатом в октябре 
Дифференциация заработной платы в национальной экономике Беларуси ...

Таблица 2

Среднемесячная заработная плата по регионам Республики Беларусь, руб.

\begin{tabular}{|c|c|c|c|c|c|c|c|c|c|}
\hline \multirow[b]{2}{*}{ Год } & \multirow[b]{2}{*}{ 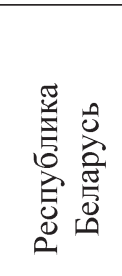 } & \multirow[b]{2}{*}{$\sum_{\dot{L}}^{\frac{\breve{L}}{0}}$} & \multicolumn{6}{|c|}{ Область } & \multirow[b]{2}{*}{ 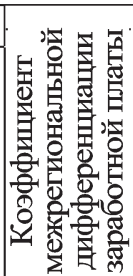 } \\
\hline & & & 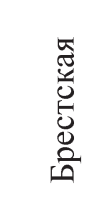 & 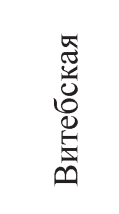 & 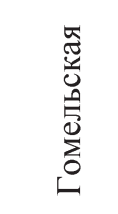 & 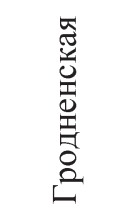 & 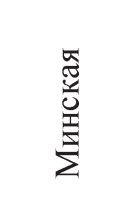 & 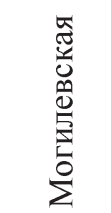 & \\
\hline 2010 & 121,7 & 153,7 & 108,8 & 109,0 & 115,2 & 110,5 & 118,2 & 109,0 & 1,41 \\
\hline 2011 & 190,0 & 240,4 & 164,7 & 170,9 & 179,0 & 171,5 & 187,8 & 171,3 & 1,46 \\
\hline 2012 & 367,6 & 457,5 & 318,5 & 331,3 & 351,7 & 329,7 & 366,0 & 336,5 & 1,44 \\
\hline 2013 & 506,1 & 636,8 & 443,1 & 450,7 & 481,6 & 457,9 & 496,2 & 453,6 & 1,44 \\
\hline 2014 & 605,2 & 773,1 & 529,4 & $\begin{array}{l}533,8 \\
\end{array}$ & 564,2 & 542,7 & 598,7 & 531,1 & 1,46 \\
\hline 2015 & 671,5 & 887,3 & 575,7 & 580,5 & 609,6 & $\begin{array}{l}592,0 \\
\end{array}$ & $\begin{array}{l}666,8 \\
\end{array}$ & 579,1 & 1,54 \\
\hline 2016 & 722,7 & 9855,8 & 617,4 & 613,4 & 633,5 & 622,4 & 713,3 & 609,3 & 1,62 \\
\hline 2017 & 822,8 & 1125,5 & 699,1 & 687,3 & 722,9 & 703,2 & 812,9 & 690,4 & 1,63 \\
\hline 2018 & 971,4 & 1329,8 & 828,4 & 814,4 & 853,3 & 831,9 & 958,6 & 802,0 & 1,66 \\
\hline 2019 & 1090,9 & 1524,3 & 942,6 & 918,9 & 974,5 & 939,8 & 1098,3 & 898,5 & 1,70 \\
\hline 2020 & 1250,9 & 1782,2 & 1071,3 & 1050,6 & 1100,1 & 1071,8 & 1240,3 & 1018,6 & 1,75 \\
\hline
\end{tabular}

Примечание. Данные представлены в действующем масштабе цен.

Источник. Авторская разработка на основе: Номинальная начисленная среднемесячная заработная плата по областям и г. Минску. URL: https://www.belstat.gov.by/ofitsialnaya-statistika/realny-sector-ekonomiki/stoimost-rabocheysily/godovye-dannye/nominalnaya-nachislennaya-srednemesyachnaya-zarabotnaya-plata-po-oblastyam-i-g-minsku/

2019 г., позволило получить ряд следующих выводов. По результатам этого статистического наблюдения заработная плата в населенных пунктах Минской области различалась почти в 2 раза. Связано это с тем, что в Солигорском районе функционирует флагман мировой калийной промышленности ОАО «Беларуськалий». Средняя заработная плата работников в Солигорском районе (1601,5 руб.) в 2019 г. превышала столичную заработную плату (1495,2 руб.) более чем на $7 \%$. Значительные различия в уровне заработной платы (в 1,8 раза) характерны для Витебской области, где в г. Новополоцке расположен белорусский нефтеперерабатывающий гигант - ОАО «Нафтан». Заработная плата по г. Новополоцку составляла 1200,1 руб., что на 10\% превышало среднюю по стране. Высокая заработная плата характерна для г. Жодино, Минского, Дзержинского, Речицкого, Мозырского, Смолевичского, Жлобинского, Светлогорского, Островецкого районов страны, где располагаются крупные промышленные и энергетические предприятия (Белорусский автомобильный завод, Белорусский металлургический завод, Мозырский нефтеперерабатывающий завод и др.), а также для отдельных областных городов. Исключение из оценки внутрирегиональной дифференциации заработной платы областных центров и населенных пунктов с крупными градообразующими предприятиями-монополистами приводит к выравниванию последней по областям - коэффициент межрегиональной дифференциации заработной платы в этом случае сокращается до 1,25-1,35. Сопоставление же административных районов в масштабах страны показывает значительные различия в оплате труда. К примеру, у работников самого «богатого» Солигорского района и самого «бедного» Мстиславского района страны, где объем средств, направляемых на оплату труда, на $70 \%$ состоит из заработков работников сельского хозяйства и бюджетной сферы, заработная плата отличается более чем в 2,3 раза.

Очевидно, что межрегиональная дифференциация заработной платы в значительной степени определяется отраслевой структурой производства в регионах и связана с функционированием крупных промышленных предприятий, и прежде всего предприятиймонополистов с капиталоемкими технологиями, обеспечивающими получение высокой добавленной стоимости в расчете на одного работника. Между тем основными целями социально-экономического развития реги- 
онов Республики Беларусь остаются повышение уровня благосостояния населения независимо от мест его проживания и уменьшение существующих различий между регионами на основе эффективного использования их преимуществ.

\section{Межотраслевая дифференциащия заработной платы}

К конкурентным преимуществам Беларуси принято относить высокий уровень образования населения (30 место в мире согласно Human Development Report 20194), высокую квалификацию работников (в особенности в таких отраслях, как автомобилестроение, тракторное и сельскохозяйственное машиностроение, оптика, радиоэлектроника, точное приборостроение, программирование) и относительно низкую стоимость трудовых ресурсов. При этом проблемой белорусского рынка труда является наличие значительного числа вакансий и безработных одновременно, что свидетельствует о дисбалансе спроса и предложения рабочей силы по профессиональноквалификационному составу, препятствующем рациональному использованию человеческого потенциала страны. Анализ конъюнктуры рынка труда показывает, что наблюдается избыток предложения по должностям служащих, преобладает спрос на рабочие профессии, существует острая нехватка специалистов по ряду позиций. Наиболее востребованными кадрами на рынке труда являются врачи и медсестры, специалисты строительного и сельс-

${ }^{4}$ Human development report 2019: beyond income, beyond averages, beyond today: inequalities in human development in the 21st century. United Nations Development Programme. URL: http://hdr.undp.org/en/2018-update кохозяйственного профиля, квалифицированные рабочие практически всех массовых профессий. Среди служащих отмечается дефицит инженеров, технологов, программистов, спросом пользуются специалисты сельскохозяйственного производства. Одновременно отечественная статистика свидетельствует о том, что в 2019 г. только 62,1\% работников выполняли работу, соответствующую их квалификации, у 17,0\% работа ниже имеющейся квалификации, у 17,4\% - такого же уровня квалификации, но не связана с полученным образованием (табл. 3 ).

Причинами дисбалансов на рынке труда являются не только несоответствие объемов и структуры спроса и предложения рабочей силы и неспособность отечественного рыночного механизма в краткосрочном периоде реагировать на изменяющиеся требования к квалификации кадров, отсутствие действенного и эффективного государственного регулирования подготовки требуемого количества работников необходимой квалификации в национальной системе образования, но и несовершенство модели управления оплатой труда, которая не способствует нивелированию этих дисбалансов.

На этом фоне в национальной экономике Беларуси наблюдается рост дифференциации заработной платы по сферам и видам экономической деятельности. Если ранее по видам экономической деятельности она различалась в $2,5-2,7$ раза, то за $2015-$ 2020 гг. разрыв увеличился до пятикратного (табл. 4). При этом до 2014 г. в лучшем положении по оплате труда находилась финансовая и страховая деятельность, уступившая затем лидерство информации и

Таблица 3

Занятое население по уровню образования и соответствию квалификации выполняемой работе в национальной экономике Беларуси, 2019 г., \%

\begin{tabular}{|c|c|c|c|c|c|}
\hline \multirow[b]{2}{*}{ Уровень образования } & \multirow[b]{2}{*}{ Всего } & \multicolumn{4}{|c|}{ В том числе выполняемая работа } \\
\hline & & $\begin{array}{c}\text { соответствует } \\
\text { квалифи- } \\
\text { кации }\end{array}$ & $\begin{array}{l}\text { ниже } \\
\text { квалифи- } \\
\text { кации }\end{array}$ & $\begin{array}{l}\text { выше } \\
\text { квалифи- } \\
\text { кации }\end{array}$ & \begin{tabular}{|c|} 
соответствует уровню, \\
а не профилю \\
образования
\end{tabular} \\
\hline Высшее & 100,0 & \begin{tabular}{|l|}
68,7 \\
\end{tabular} & 15,9 & 1,3 & 14,1 \\
\hline Среднее специальное & 100,0 & 51,5 & 27,9 & 3,1 & 17,5 \\
\hline Профессионально-техническое & 100,0 & 54,5 & 16,0 & 3,1 & 26,4 \\
\hline Общее среднее & 100,0 & 77,5 & 4,5 & 10,2 & 7,6 \\
\hline Общее базовое & 100,0 & 79,7 & 4,8 & 9,6 & 6,0 \\
\hline Всего & 100,0 & 62,1 & 17,0 & 3,6 & 17,4 \\
\hline
\end{tabular}

Источник. Авторская разработка на основе: Труд и занятость в Республике Беларусь: стат. сборник. 2020. Минск: Национальный статистический комитет Республики Беларусь. С. 39. 
Дифференциация заработной платы в национальной экономике Беларуси ...

Таблица 4

Среднемесячная заработная плата по видам экономической деятельности в национальной экономике Беларуси, 2011-2020 гг.

\begin{tabular}{|c|c|c|c|c|c|c|c|c|c|c|}
\hline Вид экономической деятельности & 2011 & 2012 & 2013 & 2014 & 2015 & 2016 & 2017 & 2018 & 2019 & 2020 \\
\hline Вся экономика & 1900 & 3676 & 5061 & 6052 & 6715 & 722,7 & 822,8 & 971,4 & 1092,9 & 1250,9 \\
\hline $\begin{array}{l}\text { Сельское, лесное и рыбное } \\
\text { хозяйство }\end{array}$ & 1328 & 2759 & 3846 & 4584 & 4928 & 506,9 & 585,2 & 684,7 & 787,1 & 919,2 \\
\hline Промышленность & 2084 & 4036 & 5470 & 6350 & 6861 & 750,9 & 869,1 & 1012,0 & 1125,5 & 1290,3 \\
\hline Строительство & 2101 & 4222 & 6385 & 7604 & 7547 & 736,2 & 818,8 & 973,0 & 1159,1 & 1388,0 \\
\hline $\begin{array}{l}\text { Оптовая и розничная торговля; } \\
\text { ремонт автомобилей и мотоциклов }\end{array}$ & 1679 & 3255 & 4572 & 5598 & 6201 & 665,5 & 769,3 & 891,3 & 977,2 & 1120,1 \\
\hline $\begin{array}{l}\text { Транспортная деятельность, } \\
\text { складирование, почтовая } \\
\text { и курьерская деятельность }\end{array}$ & 1917 & 3879 & 5316 & 6154 & 6737 & 730,0 & 813,3 & 959,8 & 1055,0 & 1198,2 \\
\hline $\begin{array}{l}\text { Услуги по временному } \\
\text { проживанию и питанию }\end{array}$ & 1239 & 2491 & 3543 & 4304 & 4805 & 515,9 & 567,2 & 652,6 & 732,9 & 808,7 \\
\hline Информация и связь & 3131 & 5881 & 8065 & 10364 & 15790 & 2033,1 & 2376,6 & 2777,2 & 3178,8 & 4116,1 \\
\hline $\begin{array}{l}\text { Финансовая и страховая } \\
\text { деятельность }\end{array}$ & 3329 & 6101 & 8321 & 10259 & 11447 & 1284,0 & 1415,7 & 1571,2 & 1713,8 & 1897,6 \\
\hline $\begin{array}{l}\text { Операции с недвижимым } \\
\text { имуществом }\end{array}$ & 1504 & 2899 & 4313 & 5125 & 5735 & 595,2 & 725,0 & 874,0 & 953,9 & 1008,4 \\
\hline $\begin{array}{l}\text { Профессиональная, научная } \\
\text { и техническая деятельность }\end{array}$ & 2670 & 4707 & 6645 & 7979 & 8965 & 985,6 & 1112,7 & 1299,2 & 1435,2 & 1611,1 \\
\hline $\begin{array}{l}\text { Деятельность в сфере } \\
\text { административных } \\
\text { и вспомогательных услуг }\end{array}$ & 1581 & 3014 & 4295 & 5358 & 6008 & 592,6 & 639,2 & 758,3 & 829,1 & 816,2 \\
\hline Государственное управление & 2160 & 4029 & 5909 & 7339 & 8362 & 881,3 & 999,3 & 1296,0 & 1321,0 & \\
\hline Образование & 1496 & 2781 & 3476 & 4178 & 4895 & 515,6 & 567,5 & 665,0 & 774,3 & 866,6 \\
\hline $\begin{array}{l}\text { Здравоохранение и социальные } \\
\text { услуги }\end{array}$ & 1576 & 3013 & 3770 & 4600 & 5449 & 574,8 & 626,8 & 739,0 & 852,8 & 1094,2 \\
\hline $\begin{array}{l}\text { Творчество, спорт, развлечения } \\
\text { и отдых }\end{array}$ & 1776 & 3237 & 4085 & 4767 & 5546 & 584,5 & 615,0 & 734,1 & 833,3 & 891,9 \\
\hline $\begin{array}{l}\text { Предоставление прочих видов } \\
\text { услуг }\end{array}$ & 1328 & 2591 & 3681 & 4672 & 5262 & 576,2 & 620,5 & 735,8 & 798,5 & 874,4 \\
\hline $\begin{array}{l}\text { Коэффициент дифференциации } \\
\text { заработной платы по видам } \\
\text { экономической деятельности }\end{array}$ & 2,69 & 2,45 & 2,39 & 2,48 & 3,29 & 4,01 & 4,19 & 4,18 & 4,34 & 5,09 \\
\hline
\end{tabular}

Источник. Авторская разработка на основе: Труд и занятость в Республике Беларусь: стат. сборник. 2020. Минск: Национальный статистический комитет Республики Беларусь. С. 236-237; Номинальная начисленная средняя заработная плата работников Республики Беларусь по отдельным видам экономической деятельности в 2020 году. URL: https://www.belstat.gov.by/ofitsialnaya-statistika/realny-sector-ekonomiki/stoimost-rabochey-sily/graficheskiy-materialgrafiki-diagrammy/

связи, сохраняющееся и сегодня. Значительно выше среднего оплачивается труд в сфере государственного управления, профессиональная, научная и техническая деятельность (деятельность в области права и бухгалтерского учета, научные исследования и разработки и др.). К аутсайдерам традиционно относятся следующие виды деятельности: услуги по временному проживанию и питанию, сельское, лесное и рыбное хозяйство, образование.

Сопоставление уровня заработной платы работников с уровнем их образования, отражаемым показателем доли работников с высшим и средним специальным образованием, в разрезе видов экономической де- ятельности, на основе расчета коэффициента ранговой корреляции Спирмена, показало отсутствие статистически значимой связи между квалификацией работников и их заработной платой, что является общей тенденцией многих лет. Наибольший разрыв между уровнями этих параметров наблюдается в образовании, где размер заработной платы несправедливо низок. Уровень заработной платы педагогических работников, имеющих сопоставимый с работниками государственного управления уровень образования, ниже (за исключением 2011, 2012, 2016 гг.), чем в сельском, лесном и рыбном хозяйстве, где заняты наименее образованные работники. 
Важнейший для национальной экономики Беларуси вид экономической деятельности - промышленность, где занято около 1 млн чел. Она представлена большим спектром производств, значительно различающихся как условиями функционирования, так и результатами деятельности, уровнем заработной платы работников (табл. 5). Дифференциация заработной платы в рамках промыш- ленности менее глубока, чем ее различия по видам деятельности. При этом она достаточно стабильна, что обусловлено большим влиянием на ее формирование рыночных механизмов и меньшим - регулируемых перераспределительных процессов, что косвенно указывает на невысокую эффективность государственного управления в сфере оплаты труда и несовершенство фискальной по-

Таблица 5

Среднемесячная заработная плата в промышленности Республики Беларусь, 2011-2020 гг.

\begin{tabular}{|c|c|c|c|c|c|c|c|c|c|c|}
\hline Вид промышленной деятельности & 2011 & 2012 & 2013 & 2014 & 2015 & 2016 & 2017 & 2018 & 2019 & 2020 \\
\hline Промышленность & 2084 & 4036 & 5470 & 6350 & 6861 & 750,9 & 869,1 & 1012,0 & 1125,5 & 1290,3 \\
\hline Горнодобывающая промышленность & 2091 & 6324 & 8365 & 9532 & 10061 & 1144,8 & 1347,7 & 1678,2 & 1854,8 & 2083,7 \\
\hline Обрабатывающая промышленность & 2095 & 4059 & 5457 & 6295 & 6766 & 741,0 & 856,5 & 995,5 & 1112,1 & 1284,1 \\
\hline $\begin{array}{l}\text { производство продуктов питания, } \\
\text { напитков и табачных изделий }\end{array}$ & 1992 & 3877 & 5555 & 6540 & 6963 & 756,8 & 850,5 & 935,5 & 1053,9 & - \\
\hline $\begin{array}{l}\text { производство текстильных изделий, } \\
\text { одежды, изделий из кожи и меха }\end{array}$ & 1414 & 2800 & 3831 & 4403 & 4605 & 516,8 & 590,7 & 666,3 & 732,5 & - \\
\hline $\begin{array}{l}\text { производство изделий из дерева } \\
\text { и бумаги; полиграфическая } \\
\text { деятельность и тиражирование } \\
\text { записанных носителей информации }\end{array}$ & 1589 & 3031 & 4260 & 5058 & 5444 & 588,2 & 666,1 & 797,0 & 905,6 & - \\
\hline $\begin{array}{l}\text { производство кокса и продуктов } \\
\text { нефтепереработки }\end{array}$ & 3485 & 6856 & 8832 & 10184 & 11009 & 1156,3 & 1331,3 & 1633,0 & 1820,9 & - \\
\hline производство химических продуктов & 3564 & 6432 & 7927 & 9827 & 11608 & 1220,4 & 1376,3 & 1678,5 & 1838,0 & - \\
\hline $\begin{array}{l}\text { производство основных } \\
\text { фармацевтических продуктов } \\
\text { и фармацевтических препаратов }\end{array}$ & 2462 & 4540 & 5749 & 7010 & 8654 & 913,4 & 1071,0 & 1204,0 & 1330,6 & - \\
\hline $\begin{array}{l}\text { производство резиновых и пластмас- } \\
\text { совых изделий, прочих неметалличе- } \\
\text { ских минеральных продуктов }\end{array}$ & 2027 & 4058 & 5488 & 6231 & 6376 & 683,8 & 786,3 & 901,7 & 1012,4 & - \\
\hline $\begin{array}{l}\text { металлургическое производство. } \\
\text { Производство готовых } \\
\text { металлических изделий, кроме } \\
\text { машин и оборудования }\end{array}$ & 2411 & 4608 & 5959 & 6744 & 7041 & 735,9 & 881,3 & 1076,2 & 1227,7 & - \\
\hline $\begin{array}{l}\text { производство вычислительной, } \\
\text { электронной и оптической аппаратуры }\end{array}$ & 1830 & 3567 & 4937 & 6157 & 7291 & 850,0 & 1025,0 & 1140,5 & 1273,7 & - \\
\hline производство электрооборудования & 2158 & 4151 & 5558 & 6310 & 6636 & 763,3 & 854,7 & 970,5 & 1088,4 & - \\
\hline $\begin{array}{l}\text { производство машин и оборудования, } \\
\text { не включенных в другие группировки }\end{array}$ & 2175 & 4381 & 5716 & 6278 & 6497 & 721,8 & 891,0 & 1061,2 & 1155,3 & - \\
\hline $\begin{array}{l}\text { производство транспортных средств } \\
\text { и оборудования }\end{array}$ & 2384 & 4634 & 5995 & 6533 & 6850 & 750,2 & 910,4 & 1077,5 & 1218,7 & - \\
\hline $\begin{array}{l}\text { производство прочих готовых } \\
\text { изделий; ремонт, монтаж машин } \\
\text { и оборудования }\end{array}$ & 1886 & 3624 & 5036 & 5873 & 6395 & 730,6 & 816,3 & 945,3 & 1061,1 & - \\
\hline $\begin{array}{l}\text { Снабжение электроэнергией, газом, } \\
\text { паром, горячей водой } \\
\text { и кондиционированным воздухом }\end{array}$ & 2021 & 3841 & 5484 & 6715 & 7568 & 828,4 & 969,5 & 1127,5 & 1209,9 & 1328,7 \\
\hline $\begin{array}{l}\text { Водоснабжение; сбор, обработка } \\
\text { и удаление отходов, деятельность по } \\
\text { ликвидации загрязнений }\end{array}$ & 1737 & 3304 & 4832 & 5700 & 6121 & 644,6 & 733,1 & 864,2 & 965,7 & 1049,2 \\
\hline $\begin{array}{l}\text { Коэффициент дифференциации } \\
\text { заработной платы по промышленным } \\
\text { производствам }\end{array}$ & 2,52 & 2,45 & 2,31 & 2,31 & 2,52 & 2,36 & 2,33 & 2,52 & 2,53 & - \\
\hline
\end{tabular}

Источник. Авторская разработка на основе: Труд и занятость в Республике Беларусь: стат. сборник. 2020. Минск: Национальный статистический комитет Республики Беларусь. С. 236-237; Номинальная начисленная средняя заработная плата работников Республики Беларусь по отдельным видам экономической деятельности в 2020 году. URL: https://www.belstat.gov.by/ofitsialnaya-statistika/realny-sector-ekonomiki/stoimost-rabochey-sily/graficheskiy-materialgrafiki-diagrammy/ 
литики. В промышленности по уровню заработной платы лидируют производства химических продуктов, кокса и нефтепродуктов, горнодобывающая промышленность, производство фармацевтических продуктов и препаратов, производство вычислительной, электронной и оптической аппаратуры, энергетика. Бессменным аутсайдером по размеру начисленной работникам заработной платы является производство текстильных изделий, одежды, изделий из кожи и меха. Низкий уровень заработков характерен и для недавно модернизированных деревообрабатывающих производств, деятельности в сфере водоснабжения, сбора, обработки и удаления отходов. В иелом наиболее высокая заработная плата в национальной экономике Беларуси имеет место в тех производствах и видах деятельности, которые связаны с функииони- рованием естественных монополий, доступом $\kappa$ природным ресурсам, применением новейших технологий (информационных, финансовых и $ә р$.$) .$

Между тем у разных видов экономической деятельности потенциал в формировании заработной платы далеко неодинаков. Высокая заработная плата характерна для более технологичных видов деятельности, где создается большая добавленная стоимость в расчете на одного работника, обеспечивающая возможность выплаты персоналу более высокой заработной платы (рис. 3). Это же относится и к субъектам хозяйствования.

\section{Профессионально-квалификащионная дифференциачия заработной платы}

На фоне высокой межотраслевой дифференциации заработной платы в стране

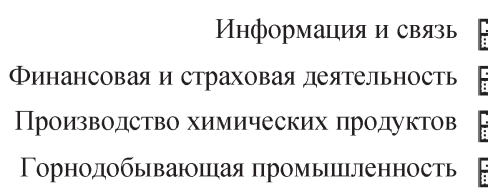

Производство кокса и продуктов нефтепереработки Производство основных фармацевтических продуктов и фармацевтических препаратов Профессиональная, научная и техническая деятельность Производство вычислительной, электронной и оптической аппаратуры Снабжение электроэнергией, газом, паром, горячей водой и кондиционированным воздухом Производство транспортных средств и оборудования Производство машин и оборудования, не включенных в другие группировки Металлургическое производство. Производство готовых металлических изделий, кроме машин и оборудования Производство электрооборудования Обрабатывающая промышленность Производство продуктов питания, напитков и табачных изделий Строительство Транспортная деятельность, складирование почтовая и курьерская деятельность Производство резиновых и пластмассовых изделий, прочих неметаллических минеральных продуктов Оптовая и розничная торговля; ремонт автомобилей и мотоциклов

Производство изделий из дерева и бумаги; полиграфическая деятельность и тиражирование записанных носителей информации Производство текстильных изделий, одежды, изделий из кожи и меха

Сельское, лесное и рыбное хозяйство Услуги по временному проживанию и питанию

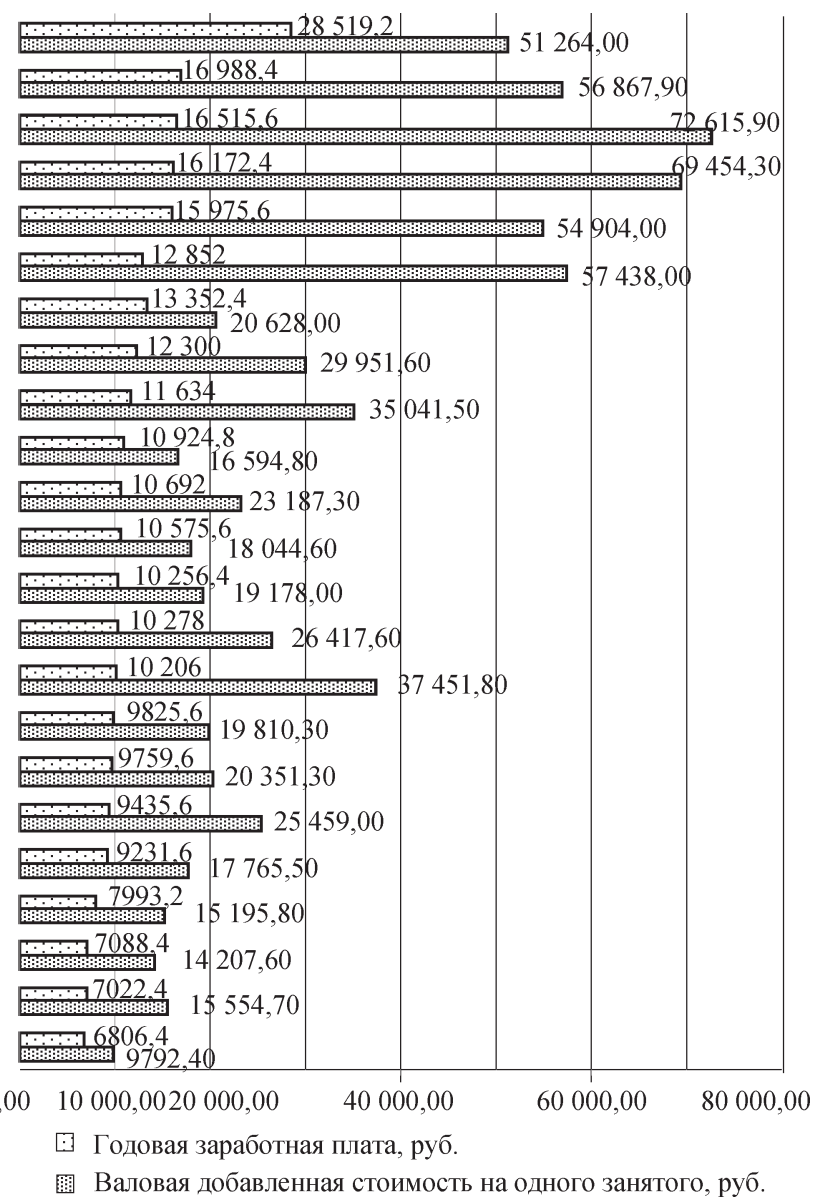

Рис. 3. Производительность труда и заработная плата по видам экономической деятельности в Беларуси, 2017 г.

Источник. Авторская разработка на основе: Труд и занятость в Республике Беларусь: стат. сборник. 2020. Минск: Национальный статистический комитет Республики Беларусь. С. 236-237; данные об объеме добавленной стоимости в расчете на одного работника по видам экономической деятельности, предоставленные Национальным статистическим комитетом Республики Беларусь по официальному запросу автора. 
наблюдается ее существенная профессионально-квалификационная дифференциация, которую целесообразно рассматривать как на уровне экономики в целом, так и в разрезе отдельных видов экономической деятельности. По данным выборочного обследования 2019 г., руководители организаций и их структурных подразделений зарабатывают в 1,5 раза больше, чем в среднем по экономике. Специалисты-профессионалы и специалисты уступают им в размере заработной платы около 15 и 38\% соответственно. При этом специалисты отстают по размеру заработной платы от квалифицированных рабочих промышленности, строительства почти на $15 \%$ и на $6 \%$ - от операторов, аппаратчиков, машинистов установок и машин, сборщиков изделий, вероятно, более дефицитных на рынке труда. Заработная плата работников сферы обслуживания, торговли и других родственных видов деятельности менее чем на 8\% превышает заработную плату неквалифицированных рабочих (табл. 6).

В целом различия в заработной плате работников по группам их занятий в рамках отдельных видов деятельности, как правило, меньше межотраслевых различий. Заработная плата руководителей в высокооплачива- емых видах деятельности (информации и связи, горнодобывающей промышленности, финансовой и страховой деятельности) в 23 раза выше средней заработной платы работников этой группы (1562,1 руб.). У специалистов-профессионалов и специалистов в информации и связи, горнодобывающей промышленности уровень заработной платы выше средней по соответствующей группе (1327,2 и 967,4 руб.) в 2-2,5 раза. Примечательно, что уровень заработной платы работников информации и связи высок по всем группам занятий. К примеру, заработная плата неквалифицированных рабочих в этом виде экономической деятельности (994,4 руб.) превышает не только заработную плату специалистов в здравоохранении (843,7 руб.), но и заработную плату специалистов-профессионалов в образовании (982,1 руб.). Самые высокооплачиваемые квалифицированные рабочие заняты в горнодобывающей промышленности (1559,8 руб.) и строительстве (1383,3 руб.), что во многом связано с неблагоприятными условиями труда.

Оценивая профессионально-должностную дифференциацию в целом по республике, необходимо отметить диспропориии, вытекающие из несовершенства межотраслевой дифференциации заработной платы, что в

Таблица 6

Среднемесячная заработная плата по группам занятий, 2019 г.

\begin{tabular}{|l|c|c|}
\hline \multicolumn{1}{|c|}{ Работники по группам занятий } & \multicolumn{2}{|c|}{$\begin{array}{c}\text { Среднемесячная } \\
\text { заработная плата }\end{array}$} \\
\cline { 2 - 3 } & руб. & $\begin{array}{c}\text { от средней } \\
\text { по экономике }\end{array}$ \\
\hline Всего & 1030,6 & 100,0 \\
\hline $\begin{array}{l}\text { Руководители коммерческих и некоммерческих организаций и руководители } \\
\text { структурных подразделений }\end{array}$ & 1562,1 & 151,6 \\
\hline Специалисты-профессионалы & 1327,2 & 128,8 \\
\hline Специалисты & 967,4 & 93,9 \\
\hline $\begin{array}{l}\text { Работники, занятые предоставлением офисных административных } \\
\text { и вспомогательных услуг, услуг потребителям, подготовкой, обработкой } \\
\text { информации и учетом }\end{array}$ & 819,3 & 79,5 \\
\hline $\begin{array}{l}\text { Работники сферы обслуживания, торговли и других родственных видов } \\
\text { деятельности }\end{array}$ & 624,8 & 60,6 \\
\hline $\begin{array}{l}\text { Квалифицированные работники сельского и лесного хозяйств, рыбоводства } \\
\text { и рыболовства }\end{array}$ & 730,1 & 70,8 \\
\hline $\begin{array}{l}\text { Квалифицированные рабочие промышленности, строительства и рабочие } \\
\text { подобных занятий }\end{array}$ & 1134,8 & 110,1 \\
\hline $\begin{array}{l}\text { Операторы, аппаратчики, машинисты и другие рабочие, занятые управлением, } \\
\text { эксплуатацией и обслуживанием установок и машин, сборщики изделий }\end{array}$ & 1032,1 & 100,1 \\
\hline Неквалифицированные работники & 580,5 & 56,3 \\
\hline Коэффициент дифференциаци заработной платы по группам занятий & 2,69 & - \\
\hline
\end{tabular}

Источник. Авторская разработка на основе: Труд и занятость в Республике Беларусь: стат. сборник. 2020. Минск: Национальный статистический комитет Республики Беларусь. С. 292-293. 
Дифференциация заработной платы в национальной экономике Беларуси ...

значительной мере обусловлено низким уровнем государственных гарантий в оплате труда (минимальной заработной плать и тарифных ставок в бюджетной сфере), не обеспечивающих разумньх стандартов и пропорчий в оплате труда различной сложности.

\section{Гендерная дифференщиащия заработной плать}

В рамках изучения дифференциации заработной платы важны не только профессионально-квалификационные, но и гендерные характеристики работников. Женщины во всем мире, как правило, зарабатывают меньше мужчин. В европейских странах гендерный разрыв в оплате труда составляет около 15\%, в значительной мере он объясняется «выпадением» женщин из активной трудовой жизни в связи с рождением детей и их занятостью в режиме неполного рабочего времени.

Особенностью трудовых ресурсов Беларуси является то, что занятые в национальной экономике женщины трудоспособного возраста по численности не уступают мужчинам, а по своим качественным характеристикам имеют преимущества перед ними. Так, женщины составляют более половины населения Беларуси (53,8\% на начало 2021 г.), их доля в составе занятого населения превышает 55\%. Белорусские женщины более образованны, чем мужчины: каждая третья из числа женщин, занятых в экономике, имеет высшее образование, каждая четвертая - среднее специальное. На конец 2019 г. 64,5\% работающих женщин имели высшее и среднее специальное образование, тогда как среди мужчин таковых было лишь 46,6\%.

Анализ распределения мужчин и женщин по категориям персонала показывает, что в конце 2019 г. руководителей среди мужчин было больше, чем среди женщин, - 12,3 и 10,0\% соответственно. В то же время большинство мужчин занято на рабочих должностях $(67,4 \%)$, тогда как женщин на таких должностях - меньше половины (42,2\%). Так, доля женщин, занятых на должностях специалистов, составляет $42,8 \%$, она значительно превосходит долю таких мужчин - 18,8\%. В целом доля руководителей и специалистов среди женщин
$(52,8 \%)$ в 1,7 раза выше, чем среди мужчин $(31,1 \%)$.

Анализируя гендерную дифференциацию заработной платы, важно учитывать и то, что в нашем обществе сформировалось деление сфер деятельности на преимущественно мужские (лесное и рыбное хозяйство, промышленность, транспорт, строительство, ремонт и эксплуатация) и женские (здравоохранение и предоставление социальных услуг, образование, финансирование и страхование, гостиницы и рестораны, торговля и бытовые услуги). При этом наблюдается преимущество мужчин в оплате труда практически во всех видах экономической деятельности, в том числе в здравоохранении и образовании. Соотношение средней заработной платы женщин и мужчин в октябре 2019 г. составило 73,1\% (табл. 7). Активисты женского движения отмечают, что в низкооплачиваемых сфеpax женщин вынуждают работать на полторы (две) ставки, что в некоторой степени маскирует гендерную дискриминацию на рынке труда.

Таким образом, несмотря на то, что белорусские женщины более образованны и чаще мужчин занимают должности руководителей и специалистов, по уровню заработной платы они им значительно уступают. Гендерная дискриминащия женщин во многом обусловлена низким уровнем государственных гарантий в оплате труда.

\section{Анализ рентной структуры заработной платы}

Анализ дифференциации заработной платы в национальной экономике Беларуси, выполненный в различных ракурсах за последние 10 лет (табл. 8), свидетельствует о ее углублении и нарастании в этой связи социального неравенства.

Сегодня очевидна необходимость упорядочения пропорций в оплате труда с учетом усиления значимости профессиональноквалификационных признаков. Разработка мер, обеспечивающих это упорядочение, предполагает понимание механизма формирования различий в оплате труда. В теоретическом плане этот механизм раскрывает авторская концепция социально-трудовой ренты, рассматривающая заработную плату как рентный доход работника, образуемый в резуль- 
Соотношение заработной платы мужчин и женщин по видам экономической деятельности в национальной экономике Беларуси, октябрь 2019 г.

\begin{tabular}{|l|c|}
\hline \multicolumn{1}{|c|}{ Вид экономической деятельности } & Соотношение, \% \\
\hline Вся экономика & 73,1 \\
\hline Сельское, лесное и рыбное хозяйство & 89,6 \\
\hline Промышленность & 73,6 \\
\hline Строительство & 81,8 \\
\hline Оптовая и розничная торговля; ремонт автомобилей и мотоциклов & 71,9 \\
\hline Транспортная деятельность, складирование, почтовая и курьерская деятельность & 94,1 \\
\hline Услуги по временному проживанию и питанию & 89,9 \\
\hline Информация и связь & 56,5 \\
\hline Финансовая и страховая деятельность & 72,4 \\
\hline Операции с недвижимым имуществом & 89,5 \\
\hline Профессиональная, научная и техническая деятельность & 76,9 \\
\hline Деятельность в сфере административных и вспомогательных услуг & 84,7 \\
\hline Государственное управление & 85,5 \\
\hline Образование & 90,4 \\
\hline Здравоохранение и социальные услуги & 80,3 \\
\hline Творчество, спорт, развлечения и отдых & 61,8 \\
\hline Предоставление прочих видов услуг & 58,4 \\
\hline
\end{tabular}

Источник. Авторская разработка на основе: Труд и занятость в Республике Беларусь: стат. сборник. 2020. Минск: Национальный статистический комитет Республики Беларусь. С. 270.

Таблица 8

Показатели дифференциации заработной платы в национальной экономике Беларуси, 2011-2020 гг.

\begin{tabular}{|l|c|c|c|c|c|c|c|c|c|c|}
\hline \multicolumn{1}{|c|}{ Показатель } & 2011 & 2012 & 2013 & 2014 & 2015 & 2016 & 2017 & 2018 & 2019 & 2020 \\
\hline $\begin{array}{l}\text { Соотношение медианной и средней } \\
\text { заработной платы (май) }\end{array}$ & - & - & 0,83 & 0,82 & 0,78 & 0,76 & 0,75 & 0,75 & 0,75 & 0,73 \\
\hline $\begin{array}{l}\text { Коэффициент межрегиональной } \\
\text { дифференциции заработной платы }\end{array}$ & 1,46 & 1,44 & 1,44 & 1,46 & 1,54 & 1,62 & 1,63 & 1,66 & 1,70 & 1,75 \\
\hline $\begin{array}{l}\text { Коэффициент дифференциации заработной } \\
\text { платы по видам экономической деятельности }\end{array}$ & 2,69 & 2,45 & 2,39 & 2,48 & 3,29 & 4,01 & 4,19 & 4,18 & 4,34 & 5,09 \\
\hline $\begin{array}{l}\text { Соотношение заработной платы женщин и } \\
\text { мужчин, \% }\end{array}$ & 73,7 & 74,5 & 74,5 & 76,6 & 76,2 & 78,5 & 74,6 & 73,7 & 73,1 & - \\
\hline
\end{tabular}

Источник. Авторская разработка по результатам исследований.

тате применения его способностей к труду в конкретной хозяйственной системе как определенной комбинации факторов производства. Анализ рентной структуры заработной платы применительно к национальной экономике Беларуси представляет практическое преломление этой концепции.

Анализ данных о заработной плате работников по группам занятий, видам выплат, категориям персонала, видам экономической деятельности (по материалам выборочного обследования организаций за октябрь 2016 г.) позволил установить, что абсолютная сочиально-трудовая рента (минимум средств существования работника) в отечественной экономике приблизительно соответствует минимальному потреби- тельскому бюджету одного члена семьи из четырех человек (табл. 9).

Исходя из этого далее по данным выборочного обследования организаций за октябрь 2019 г. был рассчитан уровень дифференциальной социально-трудовой ренты по группам занятий ${ }^{5}$ и видам экономической деятельности, который определялся как разница между средней заработной платой и МПБ, выраженная в процентах от последнего. Ее уровень минимален у неквалифицированных рабочих в таких сферах, как образование, здравоохранение и социальные услуги, творчество, спорт, развлечения и отдых (12-22\%).

5 Занятие - набор работ, характеризующихся высокой степенью совпадения выполняемых основных задач и обязанностей. 
Дифференциация заработной платы в национальной экономике Беларуси ...

Таблица 9

\section{Минимальные заработки неквалифицированных рабочих в национальной экономике Беларуси, октябрь 2016 г.}

\begin{tabular}{|l|c|}
\hline Заработная плата по видам деятельности & $\begin{array}{c}\text { Сумма, } \\
\text { руб. }\end{array}$ \\
\hline Образование & 277,6 \\
\hline Здравоохранение и социальные услуги & 290,6 \\
\hline Творчество, спорт, развлечения и отдых & 294,8 \\
\hline Горнодобывающая промышленность & 305,1 \\
\hline Минимальная заработная плата & 239,4 \\
\hline $\begin{array}{l}\text { Бюджет прожиточного минимума } \\
\text { в среднем на душу населения }\end{array}$ & 175,5 \\
\hline $\begin{array}{l}\text { Минимальный потребительский бюджет } \\
\text { одного члена семьи из четырех человек } \\
\text { (МПБ) }\end{array}$ & 285,4 \\
\hline
\end{tabular}

Источник. Авторская разработка на основе: Труд и занятость в Республике Беларусь: стат. сборник. 2020. Минск: Национальный статистический комитет Республики Беларусь. С. 290-291.

С другой стороны, у руководителей организаций и структурных подразделений в горнодобывающей промышленности, финансовой и страховой деятельности дифференциальная рента превышает $600 \%$, а в информации и связи достигает $1080 \%$. В этих трех видах деятельности в целом обнаруживается относительно высокий уровень ренты по всем группам занятий. Низка дифференциальная рента у работников образования, здравоохранения и сферы социальных услуг. Так, размер дифференциальной ренты специалистовпрофессионалов из сферы образования (166\%), занятых сложным, а нередко и уникальным трудом, заметно ниже, чем у специалистов-профессионалов в целом по экономике $(259 \%)$, ниже он, чем у квалифицированных рабочих, занятых в отечественной промышленности и строительстве (207\%), и сопоставим с размером этой ренты у неквалифицированных работников информации и связи (169\%), труд которых прост и воспроизводим.

Анализ вариации уровня дифференциальной ренты позволил получить ряд интересных выводов. Во-первых, он дал возможность выявить неоднородность состава работников в рамках каждой из групп занятий с позиций возможности получения ими дифференциальной ренты в связи с их занятостью в различных видах экономической деятельности (коэффициент вариации в каждой группе занятий в 1,5-2 раза превышает кри- тическое 33\%-е значение), что указывает на большое влияние на заработную плату конкурентоспособности хозяйственной системы. Во-вторых, дисперсия уровня дифференциальной ренты между группами занятий, по сути характеризующая влияние на заработную плату различий в сложности труда, а значит и конкурентоспособности работников, оказалась существенно меньше средней из дисперсий, исчисляемых в каждой из групп занятий в разрезе видов экономической деятельности. Из этого следует, что колебания в размерах вознаграждения за труд в большей степени определяются занятостью работников в том или ином виде экономической деятельности, чем их профессиональной принадлежностью к той или иной группе занятий (62 и 38\% от общей вариации уровня дифференциальной ренты соответственно). То есть влияние конкурентоспособности хозяйственной системы на уровень заработной платы более чем в 1,6 раза превышает влияние на нее конкурентоспособности работников, что нарушает принципы социальной справедливости и является предпосылкой снижения трудовой активности и повышения текучести персонала.

В целом установлено, что на начало 2020 г. в структуре средней заработной платы абсолютная рента составляла около $30 \%$, она совпадала с величиной минимального потребительского бюджета и минимальной заработной платой. На долю дифференциальной ренты приходилось $70 \%$ заработной платы, из которых лишь 26\% были связаны с профессионально-квалификационными различиями, а 44\% - с конкурентоспособностью хозяйственной системы, что объясняет происхождение диспропорций в оплате труда и профессионально-статусных деформаций, низкий уровень трудовой мотивации, свидетельствует о невысокой эффективности управления оплатой труда в национальной экономике.

Надо полагать, что высокий уровень дифференциальной ренты, наблюдаемый в заработной плате работников информации и связи, финансовой и страховой деятельности, горнодобывающей промышленности, обусловлен получением субъектами хозяйствования этих видов деятельности монопольной ренты, т. е. можно смело говорить о ее нали- 
чии в структуре заработной платы. В нашем исследовании монопольная рента условно «растворена» в дифференциальной ренте и отдельно в разрезе видов экономической деятельности не вычленялась в связи с отсутствием корректных подходов. Однако обосновать ее наличие позволяют следующие аргументы. В Республике Беларусь в мае 2020 г. около 6\% работников была начислена заработная плата 6 , в эквиваленте превышающая 3000 долл. США по паритету покупательной способности (ППС), что соответствует средней заработной плате по кругу наиболее развитых стран мира, при этом уровень заработной платы в стране (1560 долл. США по ППС) был ниже среднемирового уровня (1600 долл. США по ППС $)^{7}$. Монопольная социально-трудовая рента в информации и связи, финансовой и страховой деятельности имеет технологический характер, в горнодобывающей промышленности - природный. Все обозначенные виды деятельности связаны с функционированием мировых рынков, что позволяет им участвовать в формировании и распределении глобальной ренты.

Таким образом, анализ рентной структуры заработной платы показал существенное неравенство возможностей работников в части обеспечения эффективной занятости и получения достойной заработной платы. Невысокий уровень средней заработной платы в национальной экономике и ее необоснованная дифференциация в межотраслевом, профессионально-квалификационном, региональном и гендерном разрезах создают предпосылки для демотивации работников и дестабилизации трудовых коллективов.

\section{Основные направления реформирования оплаты труда в нащиональной әкономике Беларуси}

Анализ дифференциации заработной платы в контексте авторской концепции

${ }^{6}$ Распределение численности работников по размерам начисленной заработной платы в мае 2020 г. URL: https:// www.belstat.gov.by/ofitsialnaya-statistika/realny-sectorekonomiki/stoimost-rabochey-sily/operativnye-dannye/ raspredelenie-chislennosti-rabotnikov-po-razmeram-nachislennoyzarabotnoy-platy/

7 Заработная плата в мире в 2016-2017 гг. Неравенство в оплате труда на предприятиях. International Labour Organization. URL: https://www.ilo.org/moscow/news/ WCMS_538290/lang-ru/index.htm социально-трудовой ренты вскрыл невысокую эффективность национальной модели управления оплатой труда, порождающей диспропорции в оплате труда работников различных профессионально-квалификационных групп. В результате снижается трудовая мотивация и подрывается социальная справедливость, что ведет к деградации рабочей силы и препятствует инновационному развитию хозяйственной системы страны. Оплата труда работников одной и той же профессии и квалификации может в разы различаться в зависимости от того, в каком сегменте белорусской экономики они оказались. Такое расслоение затрудняет формирование гармоничного народнохозяйственного комплекса и консолидацию общества, «обескровливает» многие виды деятельности. Перед экономикой Республики Беларусь стоит задача упорядочения пропорций в размерах заработной платы различных профессионально-квалификационных групп работников с учетом их общественной значимости для поддержания национальной конкурентоспособности.

Анализ формирования заработной платы позволил смоделировать фактическую рентную структуру средней заработной платы в стране на основе следующих данных: средняя заработная плата работников в Республике Беларусь за декабрь 2019 г. (1239 руб.); величина минимального потребительского бюджета на одного члена семьи из четырех человек, установленного с 1 ноября 2019 г. по 31 января 2020 г. (372 руб.); минимальная заработная плата, установленная с 1 января 2020 г. (375 руб.); базовая тарифная ставка (БТС), установленная с 1 января 2020 г. для бюджетных организаций (185 руб.); установленная по результатам выборочного обследования заработной платы в октябре 2019 г. пропорция распределения дифференциальной социально-трудовой ренты на обусловленную конкурентоспособностью работников и конкурентоспособностью хозяйственной системы $(26: 44)$.

В фактической структуре заработной платы 30\% приходится на минимальную заработную плату (МЗП), соответствующую МПБ, что является минимумом средств существования (МСC) и определяет величину абсолютной социально-трудовой рен- 
Дифференциация заработной платы в национальной экономике Беларуси ...

ты (АР) (см. табл. 8). На долю дифференциальной социально-трудовой ренты приходятся оставшиеся $70 \%$ заработной платы. Дифференциальная рента (ДР) условно может быть разделена на две части: обусловленную конкурентоспособностью среднего работника (ДР ${ }_{\mathrm{p}}$ ) и связанную с конкурентоспособностью хозяйственной системы (ДР $\left.{ }_{\mathrm{xc}}\right)$, которые составляют в рентной структуре средней заработной платы 26 и 44\% соответственно. Отсюда следует, что заработная плата работников в большей степени определяется эффективностью функционирования организации как хозяйственной системы, чем профессионально квалификационными характеристиками работников, что в целом объясняет невысокий уровень мотивации к труду и низкую его производительность.

Исходя из анализа рентной структуры средней заработной платы в рамках воспроизводственного подхода, смоделирована эталонная структура заработной платы, позволяющая устранить диспропорции в сфере оплаты наемного труда. Она предусматривает увеличение удельного веса МЗП в структуре средней заработной платы с 30 до $50 \%$ за счет включения в нее части дифференциальной социально-трудовой ренты, необходимой для обеспечения воспроизводства населения (ДР $)$ и установления нижнего порога эффективности функционирования хозяйственных систем; рост доли дифференциальной социальнотрудовой ренты, обусловленной конкурентоспособностью среднего работника, с 26 до 33\%; сокращение доли дифференциальной социально-трудовой ренты, обусловленной конкурентоспособностью хозяйственной системы, с 44 до 17\% (рис. 4).

Переход к эталонной структуре заработной платы предполагает реализацию следующих мер ${ }^{8}$ : постепенное увеличение размера минимальной заработной платы до величины базового воспроизводственного бюджета (БВБ) $)^{9}$ на основе усиления организационно-технического нормирования труда и введения прогрессивного налогообложения дифференциальной (монопольной) социально-трудовой ренты; развитие тарифного нормирования заработной платы (увеличение базовой тарифной ставки (БТС) до уровня минимальной заработной платы, установление 10\%-х межразрядных

8 Долинина Т.Н. 2019. Институциональные модели управления оплатой труда: в 2 ч. Ч. 2. Минск: БГТУ. С. 306333.

9 Базовый воспроизводственный бюджет превышает минимальный потребительский бюджет трудоспособного населения в 1,3 раза (коэффициент иждивенческой нагрузки).

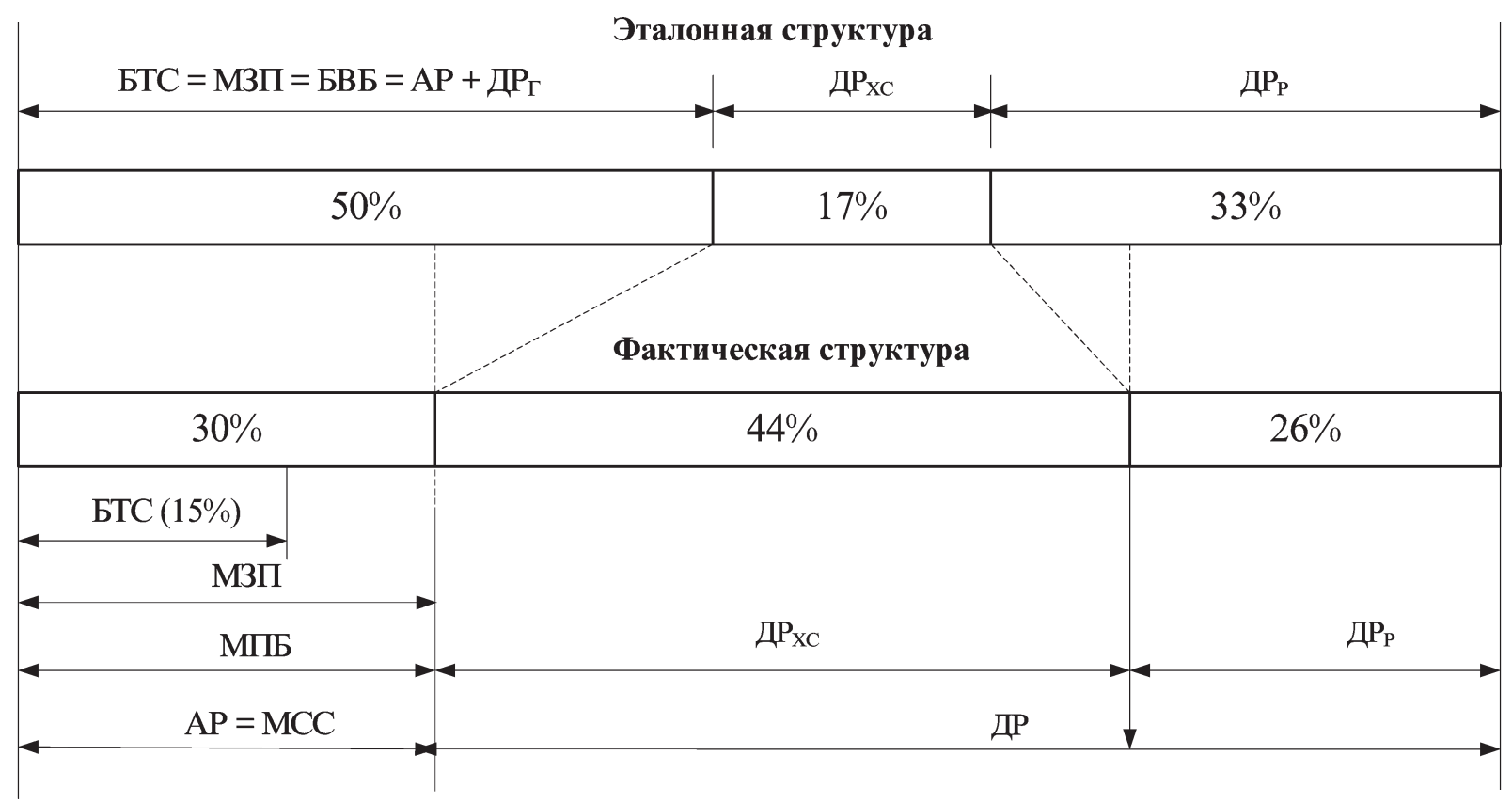

Рис. 4. Структура заработной платы работников в Республике Беларусь

Источник. Авторская разработка по результатам исследований. 
разниц в тарифных ставках) и коллективно-договорного регулирования оплаты труда для улучшения пропорций в оплате труда различной сложности путем перераспределения дифференциальной социально-трудовой ренты (ДР) в пользу ее части, обусловленной конкурентоспособностью работников (ДР $\left.{ }_{\mathrm{p}}\right)$, за счет уменьшения доли, связанной с различиями в конкурентоспособности субъектов хозяйствования (ДР $\left.{ }_{\mathrm{xc}}\right)$, в соотношении 2: 1 в соответствии с правилом «золотого сечения» (Крючкова, 2019; Неверов, 2019). Переход на прогрессивное налогообложение рассматривается как необходимая мера, обусловленная природой заработной платы как социально-трудовой ренты. В его пользу свидетельствует и опыт наиболее успешных экономик мира.

Таким образом, анализ рентной структуры заработной платы в Беларуси позволил установить, какие институты управления оплатой труда должны быть первоочередными. По мнению автора, их развитию должна предшествовать разработка Концепции реформирования оплаты труда в национальной экономике Беларуси по аналогии с концепциями 1991 г. и 1995 г., которые предваряли качественно новые этапы становления национальной модели управления оплатой труда, а именно этап формирования рыночной модели оплаты труда (19911995 гг.) и этап упорядочения оплаты труда (1995-2002 гг.). Появление такой концепции даст возможность избежать ошибок, допущенных при реформировании оплаты труда в бюджетной сфере в 2020 г., - определиться с целями и задачами в части совершенствования оплаты труда, увязав их достижение с развитием конкретных институциональных инструментов.

\section{СПИСОК ЛИТЕРАТУРЫ (REFERENCES)}

Башина О.Э., Матраева Л.В., Васютина Е.С. 2019. Алгоритм использования статистико-наукометрического анализа для выявления прогрессивных направлений научного знания в области экономики труда. Вопросы статистики. Т. 26. № 2. С. 53-66. [Bashina O.E., Matraeva L.V., Vasyutina Ye.S. 2019. Algorithm for applying statistics and scientometric analysis to identify innovative areas of focus in scientific knowledge in labour economics. Voprosy statistiki. Vol. 26. No 2. PP. 53-66. (In Russ.)]

Безгодов А.В. 2017. Планетарная рента как инструмент решения планетарных проблем. СанктПетербург: Питер. 480 с. [Bezgodov A.V. 2017. Planetary rent as a tool for solving planetary problems. Sankt-Peterburg: Piter. 480 p. (In Russ.)]

Давыдов Д., Фишман Л. 2015. Грядущее рентное общество. Свободная мысль. № 5. С. 151164. [Davydov D., Fishman L. 2015. The future rental society. Svobodnaya mysl'. No 5. PP. 151164. (In Russ.)]

Крючкова И. 2019. Экономическая теория и естественный закон. Экономическая теория. № 2. C. 5-28. etet.org.ua/docs/ET_19_2_05_ru.pdf [Kryuchkova I. 2019. Economic Theory and Natural Law. Ekonomicheskaya teoriya. No 2. PP. 5-28. (In Russ.)]

Неверов Д.А. 2019. Золотое сечение как принцип коэволющионного развития. Минск: Мисанта. 244 c. [Neverov D.A. 2019. The Golden Ratio as a Principle of Co-Evolutionary Development. Minsk: Misanta. 244 p. (In Russ.)]

Рудаков М.Н. 2014. Рента в оплате труда. Рьнок труда и рынок образовательных услуг в регионах России. URL: labourmarket.ru/conf2/ reports/rudakov.doc [Rudakov M.N. 2015. Рента в оплате труда. Rynok truda i rynok obrazovatel'nyh uslug. Regiony Rossii. (In Russ.)]

Becker G.S. 1993. Human capital: A Theoretical and Empirical Analysis with Special Reference to Education. Chicago: University of Chicago Press. 412 p.

Schultz T.W. 1971. Investment in Human Capital. The Role of Education and of Research. New York: Free Press. 272 p. 
In citation: Belorusskiy Ekonomicheskiy zhurnal. 2021. No 3. PP. 83-99.

Belarusian Economic Journal. 2021. No 3. PP. 83-99.

\title{
WAGE DIFFERENTIATION IN THE NATIONAL ECONOMY OF BELARUS IN THE CONTEXT OF MODERN RENT THEORY
}

\author{
Tatyana Dolinina ${ }^{1}$ \\ Author affiliation: ${ }^{1}$ Belarusian State Technological University (Minsk, Belarus). \\ Corresponding author: Tatyana Dolinina (tdolinina@mail.ru).
}

ABSTRACT. Based on the author's theoretical concept of social and labor rent, the differentiation of wages in the national economy of Belarus in the regional, intersectoral, professional qualification and gender aspects is analyzed. The structure of average wages has been investigated. The issues of wages management are identified; ways of their solution are suggested. rent.

KEYWORDS: wages, differentiation, social and labor rent, absolute rent, differential rent, monopoly

JEL-code: J31, J59, E24.

DOI: $10.46782 / 1818-4510-2021-3-83-99$

Received 17.08.2021 